\title{
THE CULTURAL REVOLUTION AT THE GRASS ROOTS
}

\section{Jonathan Unger*}

The Chinese Cultural Revolution as History, edited by Joseph Esherick, Paul G. Pickowicz and Andrew G. Walder. Stanford: Stanford University Press, 2006. x + 382 pp. US\$65.00 (hardcover), US\$24.95 (paperback).

Because of the headlong rush of events in China since Mao's death, research about the Cultural Revolution turmoil of 1966-68 and about the 1970s period of radical policy-making has received short shrift during recent decades. It used to be that a period was most productively studied in detail once the dust had settled, years after the events. Thus a good deal of excellent research about the 1950s was conducted during the 1960s and 1970s, and much of the important work about the 1960s, including studies of the grass-roots upheavals of the Cultural Revolution, was carried out a decade later, during the mid- to late 1970s. But with a few exceptions, during the 1980s and 1990s the traumatic periods of the 1960s and 1970s were neglected by scholars. This lamentably leaves us with too little knowledge of what transpired at the grass roots during those two earlier decades of PRC history, with large areas of important research still left undone.

It has been a missed opportunity. The Western-language research of the 1960s and 1970s was necessarily conducted from abroad through documentation and by interviewing émigrés in Hong Kong. From the 1980s onward, researchers have been able to go directly to sources within China, which can provide considerably richer information than was available to the earlier generation of scholars. However, we have not taken advantage of this, and the chance to conduct interview research about the Cultural Revolution is now dwindling. The memories of participants in the Cultural Revolution disorder of 1966-68 are fading, and the older generation of participants has begun to pass away.

The dearth of Western-language scholarship has been matched by a reluctance among PRC-based scholars to conduct studies about the Cultural Revolution turmoil, inasmuch as the government prefers that the Chinese people let sleeping dogs lie. In the 1980s the government designated publications about the Cultural Revolution upheavals of 1966-68 to be among the "Four No's", and

Thanks are owed to Anita Chan, Stanley Rosen, Warren Sun and Frederick Teiwes for helpful comments. 
even today it prefers to see the topic avoided. Only a relative handful of authors from within the People's Republic — such as Xu Youyu and Yin Hongbiao ${ }^{1}$ have persisted. Beyond the reach of censors, another handful of Chinese authors have tenaciously continued to conduct such research from abroad. ${ }^{2}$

Much of the English-language research of the 1970s, as well as the work of the few researchers today who write in Chinese, focused on the sometimes violent factionalism that erupted in the Cultural Revolution at the grass rootswithin schools, factories, offices, county towns and villages. These Cultural Revolution divisions provided a unique window on the hidden tensions and antagonisms in Chinese society in the years leading up to the Cultural Revolution. In the heat of the 1966-68 upheaval, under the cover of Maoist rhetoric, socio-economic groups that were disgruntled with their pre-Cultural Revolution situations came into conflict with groups that wished to preserve the status quo. These various groups' big-character posters and newsletters, plus interviews with émigrés in Hong Kong, provided outside observers with a goldmine of information and insight into a socio-political system that, until these upsurges from below, had remained hidden from view.

Given this background, The Chinese Cultural Revolution as History is a welcome new addition to the literature. The book's lacunae, however, lead me to go beyond a review of a single book to a full-fledged discussion of what is

1 For example, Xu Youyu, Xingxing cece de zaofan: hongweibing jingshen suzhi de xingcheng ji yanbian (The Shapes and Colors of Rebellion: The Formation and Evolution of the Spirit of the Red Guards) (Hong Kong: Chinese University Press, 1999); Xu Youyu, "Wenge zhong hongweibing de paibie douzheng" (Red Guard Factional Struggle in the Cultural Revolution), Zhongguo yanjiu (China Studies), No. 2 (Autumn 1996); Yin Hongbiao, "Hongweibing yundong de liang da chaoliu” (The Two Tidal Surges of the Red Guard Movement), Ershiyi shiji (21 ${ }^{\text {st }}$ Century), No. 13 (1993), pp. 26-38; Yin Hongbiao, "Wenhua geming zhongde wudou" (Armed Struggle in the Cultural Revolution), Zhongguo yanjiu (China Studies), No. 2 (Autumn 1996).

2 Yang Xiaokai (née Yang Xiguang), who passed away in 2004, wrote stimulating pieces in the late 1980s and early 1990s on the nature of grass-roots Cultural Revolution factionalism, in Hong Kong magazines such as Zhengming (Contention) (e.g., August 1990, pp. 68-70) and in émigré magazines such as Zhongguo zhi chun (China Spring) (e.g., August 1990, pp. 42-45). Liu Guokai, who from within China secretly wrote analyses of the grass-roots Cultural Revolution in the 1970s, has persisted in writing on this theme over the past quarter of a century in New York. He has recently published two books: Guangdong hongqipai de xingwang (The Rise and Fall of the Red Flag Faction in Guangdong) (Hong Kong: Boda Chubanshe, 2006); and Wenhua geming jianxi (A Brief Analysis of the Cultural Revolution) (Hong Kong: Boda Chubanshe, 2006). This latter book is almost entirely different from a mimeographed book of the same title which Liu Guokai penned in the 1970s while in China (see further below, note 13). Song Yongyi and several colleagues have made a prodigious effort from abroad to facilitate Cultural Revolution studies not only through their own essays but also by gathering all worthwhile documentation into CD-Roms. They have already released a massive "Cultural Revolution Database" of the official Chinese documents of the time, including memos and instructions (this CD-Rom is published by Universities Service Centre for China Studies, at the Chinese University of Hong Kong). They are preparing a second CD-Rom that will contain all of the known Red Guard newsletters and the unofficial publications of other types of grass-roots organizations. 
already known about how the Cultural Revolution affected various sectors of Chinese society, and what still needs to be found out. But let us first examine the book.

\section{The New Book's Topics}

In this new edited volume, eight young US-based scholars have published the findings of their investigations into the Cultural Revolution upheaval and the Maoist 1970s. Six of the eight are Doctoral research students at the University of California, San Diego, and two are assistant professors elsewhere in the US. A majority of them have based their chapters on fieldwork inside China, which has long been needed.

Only three of the chapters deal with the Cultural Revolution strife of 196668. The first of these, by Xiaowei Zheng, examines Red Guard factionalism at Beijing's Qinghua University, and "stresses the role of passion and ideological convictions" (p. 61). Zheng concludes that the Qinghua participants "did not base their choices solely on personal interests" (p. 63) but rather were swept up in an idealistic effort to decipher and then execute Mao's beliefs. The second of the chapters, by Dahpon David Ho, probes the Destroy the Four Olds movement of 1966-67, in which students ransacked homes and temples to destroy "feudal old culture" such as classics of literature, artwork and religious items. He focuses in particular on the unsuccessful efforts by students to lay waste to the Confucian Temple complex in Qufu, the home town of Confucius. Ho does not explore the motives of the students in the Destroy the Four Olds movement, but instead examines the brave individuals at Qufu and elsewhere who tried to protect and preserve China's cultural relics. The third of the three chapters, "Mass Killings in the Cultural Revolution: A Study of Three Provinces”, by Yang Su, is based upon county gazetteers that have been published in China during the 1980s and 1990s. He finds that the bulk of the mass killings were carried out under the auspices of local officials. All three of these chapters, in short, bypass the question of whether underlying divisions in Chinese society may have played a role in the Cultural Revolution turmoil.

The five other empirical chapters delve into later periods. The first of these chapters, by Jiangsui He, focuses on the case of a former landlord who was killed in April 1969 in the village of Yangjiagou in the last phases of the Cleansing of Class Ranks campaign. Throughout the chapter, the author assumes that harmonious relations were the natural course in the village, and only outside interference by the state upset this harmony. She even projects this absence of tensions or grievances within village society back in time to earlier eras:

Before the communists arrived, Yangjiagou was a cooperative community. Peasants worked for the Ma landlords and, in exchange, the Ma landlords provided the villagers with aid when they needed it. In the face of outside threats, landlords and peasants often worked together to safeguard their community. Moreover, in the everyday world of the village, landlords and tenants were perceived to be neighbors, relatives, and even friends (p. 150). 
This conception of the past, when generalized to Chinese villages as a whole, prompts the question of how, in the harmonious world of China, the Communists ever rose to power.

A chapter by Elya J. Zhang explores the rise and fall of Li Qinglin, a schoolteacher who gained national fame in 1973 when he wrote a letter to Chairman Mao complaining that his son, who had been sent to settle in the countryside, did not have the wherewithal to support himself. The Chairman responded sympathetically, and on the basis of Mao's reply Li rapidly rose politically in his native province of Fujian. In doing so, he opportunistically played the role of an "attack dog", to use the author's term, and the consequence was that he quickly fell when Mao died, and was sentenced to 15 years in prison. The chapter is a well-told tale of one of the most famous of the "helicopters" who ascended to power in the 1970s through a (vague) association with the Chairman or with one of his leading followers. Another chapter, by Jeremy Brown, deals with an entire village that rose into national stardom in 1974 through a chance visit by Mao's wife Jiang Qing. She admired some singing there, and before long the village was transformed through China's propaganda mills into a famous model of revolutionary singing, dancing and poetry reading. After Mao's death the village's Party secretary went to prison for a year for having become another presumptuous "helicopter".

The two remaining chapters deal with science in the 1970s and with two short novels from the post-Mao era about the experiences of urban young people who in the 1970s went to settle in the countryside. The chapter on science, by Sigrid Schmalzer, focuses on paleontology and finds that, despite the official rhetoric about scientific creativity flowing from the masses, in reality "even in the most radical period, the notion that the masses were 'superstitious' outweighed any idea that they might have had any special access to knowledge" or creativity (p. 210). The chapter by Liyan Qin compares two novellas-one from the 1980s that portrayed the sent-down youths through a rosy lens of heroism and idealism and one from the 1990s that focused on the underside of the sent-down youths' rural experiences. On the basis of these two novellas, the author concludes that only "after the failure of the 1989 student movement and the official establishment of a market economy" did Chinese writers begin "to truly turn against the Cultural Revolution and the whitewashing of its history" (p. 365). I find this conclusion puzzling, since as early as the late 1970s a school of writing had emerged in China called "wounded" or "scar" literature, which was read avidly because of its melodramatically scathing portrayal of how the Maoist 1970s affected people's lives. ${ }^{3}$ This was followed in the 1980 s by a school of writing called "reportage literature" which was even more forthright in its depiction of the terrible underside of the Maoist 1970s, ${ }^{4}$ as well as nuanced pieces

3 A sample of this literature is contained, for example, in Lu Xinhua et al., The Wounded (Hong Kong: Joint Publishing Co., 1979).

4 A powerful example is Liu Binyan's “The Second Kind of Loyalty”, available in Perry Link (ed.), Liu Binyan: Two Kinds of Truth (Bloomington: Indiana University Press, 2006), pp. 149-207. 
such as Yang Jiang's memoir of an enforced rural stay in a so-called May $7^{\text {th }}$ Cadre School. ${ }^{5}$

In sum, the new book tackles a wide range of topics that in one way or another explore how China's political sphere directly or indirectly affected events at a non-élite level from the start of the Cultural Revolution up until Mao's death a decade later. The broad sweep of subject-matter is held together by the notion that all of the chapters somehow relate to the "Cultural Revolution". Most of the individual chapters are worth reading in their own right, but I believe the book as a whole suffers from two problematical aspects: how it defines and periodizes the Cultural Revolution; and the absence of any discussion of the social divisions that were revealed in the Cultural Revolution.

\section{Periodization of the Cultural Revolution}

As has become commonplace in writings about the Cultural Revolution, the book consistently refers to the Cultural Revolution as a single decade-long period stretching from 1966 through 1976. In doing so, the chapters conflate the bottomup Cultural Revolution turmoil of 1966-68 with the politically repressive periods of 1969-76. As will be observed, this has affected some of the book's analysis and conclusions.

In the 1970s, the Chinese were quite clear in their own minds about the distinction between these periods. When I conducted interviews during the mid1970s, interviewees invariably talked about the Cultural Revolution in the past tense. It was widely accepted that it had ended with the suppression of the mass factions in the summer and autumn of 1968. By the late summer of that year, China was in the midst of what was arguably the most vicious top-down political campaign in the history of the People's Republic - the Cleansing of Class Ranks campaign. The mass organizations of the Cultural Revolution were suppressedthe exact weeks and months differed across provinces and between countryside and cities. Urban high school and university students, who had been battling each other as Red Guards, were corralled back to their classrooms, sometimes under army supervision. There they awaited assignments to the countryside or (if they were fortunate in their parentage) to urban jobs. They spent the latter part of the Cleansing of Class Ranks campaign at their new assignments (usually in villages), and witnessed the unfolding campaign there. Through the terror of this "struggle campaign", in which millions of people were persecuted and hundreds of thousands died, ${ }^{6}$ the government was determined to hammer home the lesson

$5 \quad$ Yang Jiang, Six Chapters from My Life 'Down Under' (Seattle; Hong Kong: University of Washington Press; Chinese University Press, 1984).

$6 \quad$ The numbers of people who suffered during this campaign can be gauged by reference to Guangdong Province. In 1974, the recently restored provincial Party Secretary, Zhao Ziyang, established a group to collect figures on the scale of repression in Guangdong during the Cleansing of Class Ranks period. The research group's findings were that, in Guangdong Province alone, close to 40,000 people were killed during the campaign and about a million were "struggled" against and put under "surveillance" or thrown into irregular jails (niu lan). On this see Anita Chan, Stanley Rosen and Jonathan Unger (eds), 
that the newly restored local political structures and hierarchy were to be obeyed without question. No one was left in doubt by the close of 1968 that the Cultural Revolution was over.

Very occasionally in the 1970s, when specifically discussing the top national leadership, an interviewee would indicate that the Cultural Revolution had officially ended with the $9^{\text {th }}$ Party Congress in 1969, when Lin Biao was anointed as Mao's successor. But no one whom I interviewed in the 1970s ever considered the Cultural Revolution to be ongoing. ${ }^{7}$ To them, the Cultural Revolution was a two-year period of collapsed Party control and mass turmoil-for some interviewees, an exciting and liberating time; for others, distressingly chaotic. They sharply contrasted the Cultural Revolution with the succeeding years of repressive campaigns, ${ }^{8}$ radical top-down programs in education and the economy, and a strong "class line".

Why, then does the new book obfuscate this distinction between periods? To understand this, we must look at the Chinese Communist Party's own periodization of modern Chinese history. ${ }^{9}$ Initially, Party officials spoke as though the Cultural Revolution had already ended. However, in October 1974, a pronouncement by Mao Zedong was released that stated: "The Great Proletarian Cultural Revolution is already in its eighth year. Now it's good to have stability, and the entire Party and army ought to unite". ${ }^{10}$ Nervous officials who were keen to be seen as loyal followers of Mao's every utterance duly began to refer to the Cultural Revolution in official declarations as ongoing-unlike the ordinary populace, as exemplified by interviewees. At the $11^{\text {th }}$ Party Congress in August

On Socialist Democracy and the Chinese Legal System: The Li Yizhe Debates (Armonk: M. E. Sharpe, 1985), pp. 7, 41.

7 This was also evident from some of the writings of this period. Among several examples in my bookshelf is a book of literature published in Hong Kong in 1974 by a group of young people newly arrived from the PRC, to which they gave the subtitle Selected Post-Cultural Revolution Verse by Chinese Youths (Gan you geyin dongdi ai: wenhua da geming hou Zhongguo qingnian shi wenxuan [Songs of Earth-shaking Sorrow: Selected Post-Cultural Revolution Verse by Chinese Youths]) (Hong Kong: Qishi Niandai Shuangzhoukan Chuban, 1974).

8 The devastating "One Hit, Three Antis" campaign, almost as horrific in its effects as the Cleansing of Class Ranks campaign, erupted in 1970-71. The period was also marked by a vicious mass campaign to ferret out so-called May $16^{\text {th }}$ Elements (vast numbers of people were arrested and persecuted on fabricated charges of belonging to an imaginary conspiratorial group) and other intermittent "struggle campaigns".

$9 \quad$ My discussion of periodization draws in part from Anita Chan, "Dispelling Misconceptions about the Red Guard Movement: The Necessity to Re-examine Cultural Revolution Factionalism and Periodization”, The Journal of Contemporary China, Vol. 1, No. 1 (September 1992), pp. 61-85.

10 Liu Ji (ed.), Zhongguo Gongchangdang 70 nian (70 Years of the Communist Party) (Shanghai: Shanghai Renmin Chubanshe, 1991), p. 711; also Jianguo yilai Mao Zedong wengao (Mao Zedong's Drafts since the Establishment of the PRC), Vol. 30 (Beijing: Zhongyang Wenxian Chubanshe, 1998), p. 402. I am grateful to Warren Sun for bringing these sources to my attention. 
1977, Mao's successor, Hua Guofeng, announced that the official usage could finally be terminated as of that date: "The eleven year period of our country's first Great Proletarian Cultural Revolution is declared to be successfully concluded, signified by the smashing of the Gang of Four". ${ }^{11}$ Four years later, in 1981, the Party decided to issue an official verdict on the whole period of Mao's rule, and in this "Resolution on the Historical Questions of the Party", endorsed by the Central Committee, Hua's proclamation of an "eleven-year period" was nullified. The "ten-year Cultural Revolution" was retroactively declared to have ended in 1976 with Mao's death and the arrest of the Gang of Four. ${ }^{12}$

Such a dating must have made good sense to China's top Party leaders, since Mao's death put an end to ten long years of recurrent bitter political struggles directly involving the Party élite, which had commenced with Mao's unexpected launch of the Cultural Revolution in 1966. Such a ten-year periodization also served a strategic purpose, in that it lumped together the two years of Cultural Revolution upsurge from mid-1966 to mid-1968, for which some parts of the population still felt a certain nostalgia, with the unpopular period of political repression and economic stagnation which followed in the 1970s. Many of the former Rebel Red Guards, who had been suppressed starting in 1968, despised the policies of the so-called Gang of Four officials of the 1970s. ${ }^{13}$ Nevertheless, the 1981 Resolution on the Historical Questions of the Party used the conflation of the Cultural Revolution with the "Gang of Four" period of the 1970s to blur the differences between the Rebel Red Guards of 1966-68 and the Gang of Four officials, lumping the two groups together as ultra-leftists as though they were somehow the same. By doing so, the restored Party leaders under Deng could discredit the Rebel faction, against which they still harbored strong grievances. ${ }^{14}$

11 Renmin ribao (People’s Daily), 22 August 1997; also Cheng Guoyuan et al., 1976-1981 nian de Zhongguo (China 1976-81) (Beijing: Zhongyang Wenxian Chubanshe, 1998), p. 9.

12 Hong qi (Red Flag), No. 13 (1981), p. 14.

13 A well-known illustration is the Li Yizhe group of former Rebel Red Guards in Guangzhou, who launched a famous lengthy wall-poster attack against this Maoist group of officials in 1974; this is translated in Anita Chan, Stanley Rosen and Jonathan Unger (eds), On Socialist Democracy and the Chinese Legal System, pp. 31-86. As another illustration, Yang Xiguang, the author of the famous Rebel Red Guard essay, "Whither China?", in the 1970s was vociferously opposed to the thinking of the Gang of Four officials; on this see Jonathan Unger, "Whither China?: Yang Xiguang, Red Capitalists, and the Social Turmoil of the Cultural Revolution”, Modern China, Vol. 17, No. 1 (January 1991), pp. 3-37. As a third illustration, Liu Guokai, a Rebel sympathizer who secretly wrote a monograph on the Cultural Revolution in the early 1970s, included a section on the Cultural Revolution's aftermath in which he excoriated the "Lin Biao and Jiang Qing Cliques”. See pages 130-45 of Liu Guokai, “A Brief Analysis of the Cultural Revolution”, Chinese Sociology and Anthropology, Vol. 19, No. 2 (Winter 1986-87), pp. 1-151; this journal issue was republished as a book, A Brief Analysis of the Cultural Revolution (Armonk: M. E. Sharpe, 1987), with the same page numbering.

14 Two years later, the Party leadership took its vengeance. Starting in late 1983 and continuing through 1984, a national campaign was launched to ferret out and jail "Three Kinds of People” (san zhong ren), which again conflated as targets the Cultural Revolution’s 
The "ten year" periodization of the Cultural Revolution and the conflation of periods was hammered home consistently in all subsequent mass media publications in China, and eventually was accepted unquestioningly by new generations of Chinese readers.

Not only Chinese readers fell into line. Remarkably, within just a few years of the Resolution's publication the China studies field in the West had unconsciously reworked its chronology and categorization of periods to match exactly what China's political leaders had so recently devised to meet their own political ends. That we should permit ourselves, as a field, to let the Chinese government redraw our own frame of reference and our paradigm is extraordinary-and a backward step that obfuscates the very nature of the Cultural Revolution of 1966-68.

This can be observed in the new book. As noted, only three of the eight empirical chapters focus (either wholly or partially) on the Cultural Revolution of 1966-68, while the other five chapters, which refer to themselves as Cultural Revolution chapters, focus entirely on topics from the succeeding periods. ${ }^{15} \mathrm{I}$ personally enjoyed almost all of these various chapters. They are well researched, well written, and contribute to our knowledge of these under-studied periods. But despite these chapters' merits, the point stands that the book as a whole adds to the confusion about what the Cultural Revolution constituted.

The effects of this confusion in time periods can be seen clearly, to cite one example, in the chapter on mass killings in the Cultural Revolution. The author, Yang Su, concludes:

Most mass killings took place when the party-state began to form new local governments and to demobilize mass organizations ... The fact that most of them occurred after the revolutionary committees [the title given to the reestablished local government leadership] were put in place indicates that mass killings were the result of the repression by the local state rather than the result of conflicts between independent mass groups (pp. 97, 121).

In short, most of the killings that he records were carried out under the auspices of local rural officials in the initial phases of the Cleansing of Class Ranks campaign. By considering all of the periods into the early 1970s as uniformly part of the Cultural Revolution, Yang Su ends up confusing the Cultural Revolution with its suppression and the terrible acts of vengeance

Rebel factions of 1966-68 and followers in the 1970s of the Gang of Four. The "three kinds of people" to be punished for events reaching back as much as one and a half decades were: 1) followers of Lin Biao and the Gang of Four; 2) people who had been seriously affected by factional motives; and 3) "smashers" and "grabbers" of the 1966-68 period. Large numbers of former grass-roots Rebel faction leaders were rounded up in this campaign and imprisoned.

15 The new book under review is not the only book on the "Cultural Revolution" that largely focuses on the 1969-76 period. For instance, only 11/2 chapters out of the 12 chapters of a 1991 book, New Perspectives on the Cultural Revolution (edited by William A. Joseph, Christine Wong and David Zweig [Cambridge: Harvard University Press]), involve the Cultural Revolution of 1966-68; almost the whole of that book deals with the 1970s. 
exacted at that time. This confusion is nowhere better seen than in the chapter's concluding paragraph:

This leads us to the second defining feature of the Cultural Revolution: state sponsorship. Previous research often focused on preexisting social divisions that allegedly motivated mass movements. But as I have shown above, not only did the state lead the movement through policy pronouncements, but also local state actors took the interpretations into their own hands. One of the consequences was the large-scale violence examined here.

It of course isn't the case that a defining feature of the Cultural Revolution was that it either consisted of an upsurge of mass movements or that the Cultural Revolution was under state sponsorship and was violently organized by local officials. Rather, it is a question of different time periods. Preexisting social tensions motivated the division of significant parts of the populace into opposing mass factions during the Cultural Revolution upheaval. Local officials took into their own hands how to interpret central policy pronouncements during the subsequent period in which the Cultural Revolution activities had been crushed and vengeance was exacted. Had our field retained a clear distinction between the Cultural Revolution and the repressive period that followed it, the chapter would not have possessed this sort of confusion. The bulk of the chapter is, in fact, excellent - the author's empirical research in Chinese county gazetteers about the timing of the mass killings is very well done, and the detailed page-bypage analyses are interesting and persuasive. The problem simply lies with a periodization that distorts the author's conclusions. ${ }^{16}$

\section{The Social Conflicts of the Cultural Revolution: An Unfinished Research Agenda}

As noted, the book does not address what had been a main thrust of the earlier scholarship of the 1970s: that is, research into the socio-political roots of grassroots conflicts in the Cultural Revolution. To be sure, there is nothing wrong with concentrating on other types of research topics. However, because our field has shifted its attention, a lacuna persists in our understanding of the turmoil of the Cultural Revolution. The book's editors, who are from the older generation of scholars, are well aware of the previous literature on this, and part of the book's Introduction focuses on those previous writings. But the empirical chapters have entirely turned away from such themes. One reason, of course, is that most of the chapters have nothing to do with the Cultural Revolution per se, but rather with the 1970s. Inasmuch as the Seventies have been under-studied, it is all to the good that these chapters have been researched. Indeed, an argument can be made that there is a greater need to study the Seventies than the Cultural Revolution, in

16 Almost exactly the same periodization issue holds for an article which Yang Su participated in on a similar topic: Andrew Walder and Yang Su, "The Cultural Revolution in the Countryside: Scope, Timing and Human Impact”, The China Quarterly, No. 173 (March 2003), pp. 74-101. 
that even less has been published about the later period. But the very fact that a book with "Cultural Revolution" in its title has so few chapters on the Cultural Revolution of 1966-68 points to the pressing need for our field to tackle the period of the actual Cultural Revolution before it is too late. What occurred among China's political élite during the Cultural Revolution can be examined even decades from now, as China's archives of classified material open up, but what occurred at the grass roots in the mass upheavals - and why-must be researched soon, through interviews, or it will be forever lost to history.

What, then, is known about the mass movements of the Cultural Revolution, and what still needs to be explored? During the 1970s, interviewing émigrés in Hong Kong, I was able to collect transcripts on a variety of local cases across China, most of which have never been used for publication, and in the following pages I will utilize some of this information to suggest where further research may be worthwhile. There were a substantial number of different types of upheavals in different sectors of society-and violent factionalism erupted within each of these sectors for somewhat different reasons. The question therefore needs to be asked separately for each sector.

\section{The Cultural Revolution in High Schools}

Of all the sectors of society, we know the most about why high-school students rose up and split into warring Red Guard factions. A substantial amount of research has already been accomplished on this, to the point that it is possibly the only type of Cultural Revolution mass movement which has been sufficiently researched. ${ }^{17}$

We know that China's high-school students faced increasingly difficult chances of getting admitted to a university in the years leading up to the Cultural Revolution, and increasingly difficult career prospects if they were not admitted. In these same years, the criteria laid down by the government for getting into university kept shifting, but on the whole they gave progressively greater play to

The literature on the social origins of high-school Red Guard factionalism includes Hong Yung Lee's pioneering studies based on Red Guard broadsheets, “The Radical Students in Kwangtung during the Cultural Revolution”, The China Quarterly, No. 64 (December 1975), pp. 645-83, and Lee's The Politics of the Chinese Cultural Revolution (Berkeley: University of California Press, 1978). Also see Stanley Rosen, Red Guard Factionalism and the Cultural Revolution in Guangzhou (Canton) (Boulder: Westview Press, 1982); Anita Chan, Children of Mao: Personality Development and Political Activism in the Red Guard Generation (London; Seattle: The MacMillan Press; University of Washington Press, 1985); Jonathan Unger, Education Under Mao: Class and Competition in Canton Schools, 19601980 (New York: Columbia University Press, 1982), Chs. 5-6; Anita Chan, Stanley Rosen and Jonathan Unger, "Students and Class Warfare: The Social Roots of the Red Guard Conflict in Canton”, The China Quarterly, No. 83 (Autumn 1980), pp. 397-446; the Chinese-language writings of Yang Xiaokai; and Joel Andreas, "Battling over Political and Cultural Power in the Cultural Revolution”, Theory and Society, Vol. 31, No. 4 (August 2002), pp. 463-519. A discussion of the differing perspectives of Rebel and Loyalist supporters about the divisions in Chinese society is contained in Anita Chan, "Images of China's Social Structure: The Changing Perspectives of Canton Students”, World Politics, Vol. 34, No. 3 (April 1982), especially pp. 295-316. 
a parent's class origin and less to a student's academic achievement. A third criterion was also evaluated by admissions officers: a student's political activism. This was judged in terms of whether a student had been accepted into the Communist Youth League. ${ }^{18}$ Ambitious students vied with each other to get in. The students of middling-class (yibande chengfen) origins (whose parents before the revolution had been peddlers, white-collar workers, professionals and so on) were disturbed by policies in the mid-1960s that gave increased priority in Communist Youth League admissions to students of red-class origins (the children of pre-Liberation workers, poor peasants and Communist Party cadres). In these circumstances, amidst rising tensions among students, the official policy in 1965 swung yet again, in the realization that millions of students of non-red family background were becoming discouraged at their chances of ever proving their activist political devotion. When Mao launched the Cultural Revolution in May 1966, the high-school students of red family origin took advantage of the new campaign's thrust against "bourgeois authorities" and "white experts" to set up Red Guard groups and to exclude non-red-origin students from participating. ${ }^{19}$

It was during this early phase of the Cultural Revolution, in the summer and early autumn of 1966, that the Destroy the Four Olds movement erupted. Redclass students stormed into bad-class households to destroy books, furniture and artwork, and middling-class students were only allowed to tag along as onlookers. The middling-class children of intellectuals were strongly discomfited by this display of zealotry, as the confiscated and burned objects were similar to items in their own homes. In short, the Destroy the Four Olds was used by redclass high-school students to denigrate the impurity of "bourgeois" households and to lower the esteem of their middling-class classmates and competitors. It would have been interesting if Dahpon David Ho's chapter had examined the motives of the Red Guard perpetrators of the attack against the Confucian temple complex. This is especially the case since, from his description, the organizers of this attack were not high-school students but rather university students, a sector in society that was differently motivated from high-school students (as will be seen in the next section).

In the autumn and winter of 1966, when Mao shifted the fledgling Cultural Revolution campaign more solidly against "capitalist roaders in the Party", the middling-class high-school students formed their own Red Guard groups and "turned the spearhead" away from "bourgeois authorities" and toward errant local

18 For example, Susan Shirk, Competitive Comrades: Career Incentives and Student Strategies in China (Berkeley: University of California Press, 1982); Jonathan Unger, Education Under Mao.

19 A partial exception to this scenario was the boarding high school of Dai Hsiao-ai, whose story fills the book Red Guard. The students there came from all over Guangdong Province, and in the period before the Cultural Revolution the issue of students' family origins was trumped by regional identities: students divided along the lines of where they came from and their native dialect (pp. 4-5). But even in this high school, when the Cultural Revolution erupted the red-class students banded together to form the original Red Guard organization and excluded the students of non-red origins. Gordon A. Bennett and Ronald N. Montaperto, Red Guard: The Political Biography of Dai Hsiao-ai (Garden City: Anchor Books, 1972). 
Party leaders, a group that, perhaps not entirely coincidentally, included many of the parents of their red-class schoolmates. Violent clashes between the opposing Red Guard factions erupted among high-school students across China, and in particular at the élite high schools where students had been competing most vigorously to get into a university. A recent article by Joel Andreas, discussing the élite high school attached to Beijing's Qinghua University, reconfirms this scenario-of growing tensions among students on the eve of the Cultural Revolution and a split into opposing Red Guard groups largely along class-origin lines. At this school:

During the year or so preceding the Cultural Revolution, children of revolutionary cadres [namely, children of veteran Communist officials] ... had accused the principal, Wan Bangru, of favoring children of the old educated elites. He had allowed the latter to gain undue positions in the Youth League, they complained, by failing to implement the class line policies. Children of intellectuals fought back, at one point waging a wall poster campaign criticizing the principal for caving in to parental pressure by failing to punish the son of a high cadre for fighting. Fractures were appearing ... that would develop into violent factional antagonisms during the Cultural Revolution, organized largely along lines of class origin. ${ }^{20}$

While, in the new book under review, Xiaowei Zhang's study of Qinghua University finds no discernible interest-group behavior there, at the high school right next door it was palpable.

A somewhat similar story played out in the élite high schools of Changsha in Hunan Province, ${ }^{21}$ and in Guangzhou in the far south of the country. ${ }^{22}$ In the cities for which we have information, the children of the officials overwhelmingly participated in what became known colloquially as the Loyalist or Conservative Red Guard faction, while the middling-class students from educated families gravitated overwhelmingly into the Rebel Red Guard faction. We have less information about the behavior of students from working-class families, but studies of Guangzhou show that they split down the middle in their factional allegiances. One reason was that at the non-élite junior high schools, where they predominated, fewer students were vying to climb into higher education. The split among students in these working-class junior high schools was often between the League members, who had stood over their classmates in positions of authority, and the less ambitious non-activist students, who resented the activists and became Rebel Red Guards. It should be noted, though, that the

20 Joel Andreas, "Battling over Political and Cultural Power in the Cultural Revolution”, p. 476.

21 On the experience in an élite Changsha high school, and the subsequent composition of the rebel Shengwulian faction in the Cultural Revolution, see Jonathan Unger, "Whither China?”.

22 A number of the citations in footnote 17 deal with the evidence from Guangzhou high schools: see Hong Yung Lee's China Quarterly article, and the three books and China Quarterly article by Anita Chan, Stanley Rosen and Jonathan Unger. 
working-class students who joined the loose city-wide Rebel Red Guard coalition tended to form their own groups separate from the Rebel Red Guards of less politically-correct class origins. ${ }^{23}$ Most bad-class high school students shunned any Cultural Revolution activity, knowing that they would be vulnerable and likely to suffer retribution. ${ }^{24}$

\section{Universities}

The students at universities were already the "winners" in the competition to advance through education. They did not need to worry about the same issues of class preferment and tightening university admissions that troubled ambitious high school students. All of the studies published to date, including Xiaowei Zheng's in the new book, have shown that among the university students there was scant connection between joining a Cultural Revolution faction and any concrete personal "interests". It should be noted, though, that all of the published studies have focused on élite universities in Beijing. ${ }^{25}$ There, early in the Cultural Revolution, various university student groups developed direct links to top Party

23 Anita Chan, Stanley Rosen and Jonathan Unger, “Students and Class Warfare”, p. 436.

24 David Raddock, through interviewing in Hong Kong in the 1970s, produced a good book on the bad-class students' pre-Cultural Revolution predicament and the psychological and social burdens they were forced to bear: Political Behavior of Adolescents in China: The Cultural Revolution in Kwangchow (Tucson: University of Arizona Press, 1977). An essay by a bad-class youth, Yu Luoke, on the unfairness of the class line was very widely read by Rebel Red Guards. The essay is reproduced and analyzed in Gordon White, The Politics of Class and Class Origin: The Case of the Cultural Revolution (Canberra: Contemporary China Centre, 1976).

25 For example, Victor Nee, The Cultural Revolution at Peking University (New York: Monthly Review Press, 1969); William Hinton, Hundred Day War: The Cultural Revolution at Tsinghua University (New York: Monthly Review Press, 1972); David and Nancy Milton, The Wind Will Not Subside: Years in Revolutionary China 1964-1969 (New York: Pantheon Books, 1976); Andrew Walder, "Beijing Red Guard Factionalism: Social Interpretations Reconsidered”, The Journal of Asian Studies, Vol. 61, No. 2 (May 2002), pp. 437-71; Joel Andreas, "Battling over Political and Cultural Power in the Cultural Revolution” [focusing on Qinghua University] (he brings the story forward into the 1970s in Joel Andreas, "Institutionalized Rebellion: Governing Tsinghua University during the Late Years of the Cultural Revolution”, The China Journal, No. 55 [January 2006], pp. 1-28). For his Doctoral dissertation, Stanley Rosen conducted interviewing in the 1970s with former Red Guards from the élite Beijing universities, with similar findings. (Stanley Rosen, "The Origins and Development of the Red Guard Movement in China, 1960-1968”, PhD dissertation, UCLA, 1979). In a book on student Red Guards, Anita Chan sums up the experiences of an interviewee who had attended People's University, one of this handful of élite Beijing schools: "Being in the nation's capital, each faction soon established direct links with different Central Committee members and vehemently flung the pejorative label 'Royalist' at the opposing faction, claiming for itself the revolutionary title of 'Rebel'. Both factions at Bai's university not only were tied to members of the central leadership; the conflict between the student groups was so ideologically and politically ill-defined that by 1967 both the main factions, though deadly enemies, found themselves paradoxically belonging to the same Red Guard Headquarters. From Bai's description, their squabblings often seem to have been unprincipled and petty”. Children of Mao, p. 164. 
leaders such as Mao, Jiang Qing, Kang Sheng, Zhou Enlai and others, or indirect links through the children of top leaders, and some of the student groups became, at times, unwitting pawns in the factional battles at the very top. Unfortunately, practically everything that we know about what occurred at Chinese universities is based on precisely this small group of élite Beijing universities-universities that were anomalies due to the direct links to Party leaders.

In the mid-1970s, I had an opportunity to interview two former students and a former lecturer from élite Beijing universities, and their recollections paralleled those of the published studies. But the lecturer also recalled a split along a dimension that is not evident from the others' studies:

The students acted in their own interest when the Cultural Revolution began. Those who were about to graduate were the most loyal to the Party leaders of the university, since their allocations to good job postings depended on those leaders. It was first and second-year students who were the most radical. ${ }^{26}$

What was the scenario at universities outside Beijing? B. Michael Frolic interviewed a student from Amoy (Xiamen) University in Fujian, who described Cultural Revolution struggles between the "careerist" students from "upper-class Fujian families" who were good at their studies versus "the less privileged, more politically conscious" students. ${ }^{27}$ Interviewing which I conducted in 1975 with a former student at Jinan University in Guangzhou also reveals a "class"-based conflict among students, somewhat similar to what occurred among high-school students. Jinan University was financed by overseas Chinese and accommodated large numbers of their children, and in the Cultural Revolution these students rebelled against the suspect "class label" of Overseas Merchant with which they had been saddled.

My interviews in the mid-1970s regarding two other universities-one in Yunnan and one in Guangzhou-are suggestive of another form of pre-Cultural Revolution tension that exploded into factional rivalry. According to my interviewees' descriptions, some of the most politically active students were competing to gain leadership status in the Communist Youth League or were angling to join the Party. Both interviewees claimed that these politically activist students had gained the animus of those students who concentrated instead on their studies. When the Cultural Revolution exploded, these tensions played themselves out among the interviewees' classmates as they chose one faction or the other, generally pitching the successfully activist students against the others.

26 David and Nancy Milton, who taught in Beijing at the No. 1 Foreign Language Institute [university], noted this distinction between the fifth-year class, which he taught, and the second-year class, which she taught, but they seem to have attributed it to the fact that "His class, partly because of its senior status, contained a large number of Party and League members" (The Wind Will Not Subside, p. 208). The second-year students, most of whom were the children of farmers due to a recent pre-Cultural Revolution ruling by the Foreign Ministry requiring increased worker-peasant enrolments, tended to join the opposite faction, which launched attacks against the school's First and Second Party Secretaries (p. 209). 
As the interviewee from Yunnan, who had been a student at the Yunnan Teachers-Training University, noted:

Most of the students sought safety during the Cultural Revolution by joining the majority faction. This was especially true among the older students, who were close to graduation. But a second strong factor [in determining factional allegiance] was that before the Cultural Revolution, some students could be said to have been "persecuted"- that is, they'd been afraid of being reported onwhile other students were part of the established power as political activists: opportunists who were betraying others in order to climb up. Within their own classroom group, the activists became the Loyalists and the others became the Rebels.

Interview research is sorely needed with former university students from across China, to divine whether similar or different types of splits erupted at their own universities. We have no idea today whether the most prevalent scenario at China's universities is the one described above, or the one for Beijing's universities, or the one that prevailed at Xiamen and Jinan Universities, or possibly even whether there were some other entirely different reasons for the divisions among classmates. In China today, many tens of thousands of former university students, now in their late 50 s and early 60 s, are readily accessible to be interviewed. Hopefully a researcher will sit down with some of them.

\section{Factories}

Two different types of explanations have been put forward to explain the upheavals in China's factories and the division of the workforce into warring factions. The first of these explanations is offered by Andrew Walder, in an essay based upon interviewing in Hong Kong during the 1970s as well as reading worker-faction newsletters. Walder's essay emphasizes that "conflicts within factories during the Cultural Revolution were shaped heavily-though not exclusively_by divisions created in the workforce by the Party's political networks" ${ }^{28}$ He observes that the loyalist factions were formed from among those workers who, prior to the Cultural Revolution, had been the trusted clients of a factory's Party branch. ${ }^{29}$ (This is similar to the scenario at the university in Yunnan, where activists favored by the League and Party formed the loyalist core.) Walder does not explicitly write that disgruntled workers who were

28 Andrew Walder, "The Chinese Cultural Revolution in the Factories: Party-State Structures and Patterns of Conflict”, in Elizabeth J. Perry (ed.), Putting Class in its Place: Worker Identities in East Asia (Berkeley: China Research Monograph 48, Institute of East Asian Studies, University of California, 1996), p. 169.

29 Walder also takes up this theme, from a different perspective, in a paper on how officials (including factory officials) during the Cultural Revolution upheaval made use of such trusted clients to defend themselves from rebel attacks; see Andrew Walder, "When States Unravel: How China's Cadres Shaped Cultural Revolution Politics”, in Kjeld Erik Brødsgaard and Susan Young (eds), State Capacity in East Asia (Oxford: Oxford University Press, 2000), especially pp. 178-83. 
unfavored by Party networks stood against the loyalists, joined rebel factions and attacked and toppled factory leaders, but this seems consistent with his scenario.

Interviews that I conducted in 1975-76 were in line with Walder's findings. For instance, an interviewee noted that at his factory in Yunnan Province, the "political activists" among the workers prior to the Cultural Revolution "were always ready to respond to Party orders. Their special duties were to make reports on other people”. During the Cultural Revolution other workers turned on these "old activists". Alongside this struggle, factory officials came under attack from one side or the other, and in the turmoil "almost all of them were pulled down; it wasn't a case of some types of cadres being ousted and other types not. Only some of the lowest officials survived ... After the Cultural Revolution [that is, in the early 1970s] the factory's officials have become scared to make decisions and they've shifted a lot of the decisions to the army representative in the factory".

The second type of explanation of upheaval and factionalism within factories perceives the conflict in terms of opposing constituencies that had been materially favored or unfavored prior to the Cultural Revolution. Based on worker-faction newsletters, Hong Yung Lee was the first to present this scenario: that the radical rebel worker organizations' members were "from the smaller, poorer factories, the contract and temporary workers, the apprentice and unskilled workers in the larger factories". ${ }^{30}$ Notably, the apprentices, temporary workers and contract workers had the lowest wages, did the most onerous tasks and, unlike most other workers, were entitled to few or no perquisites, and the temporary and contract workers had no job security. Walder himself sketches out a scenario that is in line with such groups principally wanting better conditions. Although he does not explicitly adopt this scenario, it appears from his evidence that, whereas the loyalist faction in a factory was shaped by support for political networks, many members of the rebel faction in a factory were motivated by complaints of material deprivation and/or job insecurity, coalescing in a tacit interest-group politics.

According to the Chinese author Liu Guokai, there was yet another dimension: younger workers gravitated toward rebel factions more often than their older colleagues, because "the younger workers had more guts than their older coworkers". ${ }^{31}$ But the younger workers may well also have been acting on material complaints about their situations and poor career prospects. Elizabeth

30 Hong Yung Lee, The Politics of the Cultural Revolution, p. 340. A tabloid published by a group of temporary and contract workers in Shanghai was quite explicit that they were rebels because they saw themselves as exploited: "The purpose of hiring temporary workers and contract workers is to make maximum profit with minimum investment. This involves exploitation of the labor and surplus value of temporary and contract workers, [who] are kept out of such organizations as the Party, the [Communist Youth] League, and the militia”. Quoted in Lynn White III, Policies of Chaos: The Organizational Causes of Violence in China's Cultural Revolution (Princeton: Princeton University Press, 1989), p. 247.

31 Liu Guokai, “A Brief Analysis”, p. 79. Liu presumably was generalizing from what he observed in Guangzhou. Hong Yung Lee reached a similar conclusion from Cultural Revolution mass-organization newsletters. 
Perry and Li Xun examined who were the leaders of rebel factions in Shanghai factories and found that a typical leader was only about 30 years old at the start of the Cultural Revolution. They hypothesize that "Having logged a number of years on the job, with scant prospects of upward or outward mobility, they were ripe for a movement that offered them a chance to challenge the status quo". ${ }^{32}$

To the extent that the Rebel groups were composed of workers who were disgruntled and wanted to upturn the status quo ante, entire workforces that had been discriminated against in pay and status joined the Rebel side en masse. According to interviewing that I conducted about the situation in the city of Changsha, the Rebel strongholds included some of the small neighborhood firms of handicraft workers and tradesmen which had been collectivized in the mid1950s: poorly capitalized operations that, by deliberate government policy, provided low wages. Another group comprised construction workers, also a lowpaying trade, where the traditional wage bonuses had been suppressed in the 1960s by the industry's political department. Yet another militant Rebel grouping was composed of transport coolies who hauled freight through city streets. A sizeable percentage of them had reportedly been in labor camps, and performed this tough, very low-paid coolie labor because no one was willing to hire political and criminal convicts for other lines of work. ${ }^{33}$

On the whole, the large "core" factories in heavy industry had been viewed by Communist Party ideology as more advanced and glorious than light industry or handicraft industry, and as a result these large factories had been favored by the government in terms of wages and workers' perquisites. The Party was also better organized there, and had nurtured more political activists. During the Cultural Revolution upheavals, the loyalist factions normally appear to have predominated in such factories, while the rebel faction had a stronger footing in the smaller factories that were less favored by Party policy and that also contained a less powerful Party presence. ${ }^{34}$

32 Elizabeth J. Perry and Li Xun, Proletarian Power: Shanghai in the Cultural Revolution (Boulder: Westview Press, 1997), p. 40.

33 For example, see Jonathan Unger, "Whither China?", for the composition of the militant Rebel Shengwulian coalition in Changsha, Hunan (p. 20).

34 Based partly on his knowledge of Guangzhou, Liu Guokai noted these differences in Loyalist and Rebel strength in large vs. small factories in "A Brief Analysis”, pp. 75-76. Notably, in some other cities, for reasons particular to the scenarios there as the Cultural Revolution unfolded, the great majority of the workforces at practically all of the factories, large as well as small, joined the Rebel camp. An interesting first-hand account of the situation in the city of Guilin, Guangxi Province, by a former student Rebel Red Guard, is Hua Linshan, Les Années Rouges (Paris: Editions de Seuil, 1987), pp. 120-35. According to my interviewing about Changsha, Hunan, the outnumbered Loyalist faction there fled the city and joined their confreres in Xiangtan, an armaments manufacturing center whose workers thereby enjoyed a higher political status and better conditions than other workers. Warfare broke out between this Loyalist city and Changsha's triumphant Rebels. When the warfare died down, Changsha's Rebel faction split into two hostile camps, the haves and have-nots. The more conservative of the Rebel groups, based on the red-class workers from large enterprises, allied themselves with red-class student groups and fought the radical 
At a small distillery in the capital city of one of China's inland provinces, where Anita Chan and I interviewed many dozens of workers and retirees during 2002-04, ${ }^{35}$ the entire workforce had belonged to the rebel faction. The distillery was part of the foodstuffs processing industry, which provided low wages and low status. Since everyone belonged to the same faction, there was no violence or turmoil within the distillery. ${ }^{36}$ Most interviewees could not articulate clearly what each of the Cultural Revolution factions stood for, or why they all wore rebelfaction armbands to work, but the fact that the distillery was solidly rebel was not a random choice - the impoverished, over-worked distillery workers had sensed at a semi-conscious level that people like themselves would fit into a Cultural Revolution rebel faction. They could not imagine that anyone who worked at such a poorly paid factory would have any other identification. An interviewee who had been appointed a Party member and "model worker" because of her ultra-red class background (before the revolution she had been sold into bonded child labor) recalls that, secretly, she was sentimentally sympathetic to the city's loyalist faction. But even she habitually wore the Rebel armband every day to work and attended rebel rallies (the factory took roll-call, she says), since her coworkers all took it for granted that everyone should. ${ }^{37}$

A few interviewees from the distillery were fully aware of why they were in the rebel faction. One of these, an elderly retiree who was a worker in his early 30s when the Cultural Revolution erupted, looks back at the Cultural Revolution period with nostalgia:

Rebels of the small, poorly regarded factories and trades and the non-red-class secondaryschool students. In some other cities, unlike Changsha, the distinctions between the warring camps became quite clouded by 1967, as the alignments of various subgroups and organizations shifted and split and re-coalesced in accordance with the vagaries of local repressions, desperate efforts to secure vengeance and to end up on the winning side, and subsequent alliances of convenience. One example is Hangzhou, the capital of Zhejiang province (Keith Forster, Rebellion and Factionalism in a Chinese Province [Armonk: M. E. Sharpe, 1990]). A second, according to my interviews, is Kunming, Yunnan. The city of Beijing could be considered a third example, though there the confused alignments at the grass roots may have originated in the groups' links to varying high-level Party leaders.

35 The nature of these interviewees' recollections is discussed in Jonathan Unger and Anita Chan, "Memories and the Moral Economy of a State Enterprise", in Ching Kwan Lee and Guobin Yang (eds), Re-envisioning the Chinese Revolution: The Politics and Poetics of Collective Memories in Reform China (Washington; Stanford: Woodrow Wilson Center Press; Stanford University Press, 2007).

36 Nevertheless, during 1967 the distillery director was locked up by the workers, as were the two leading foremen, who were seen as too strict. The latter, ironically, were principally accused of having been members of a working-class secret society, the Gelaohui, before the revolution. Such flimsy pretexts for toppling superiors seem to have sufficed during the Cultural Revolution upheaval.

37 In a personal communication to me, Stanley Rosen notes that in several interviews that he conducted about the Cultural Revolution in Guangzhou factories, the pressure to conform and "go along with the tide" (sui chaoliu) was similarly evident. For instance, a former factory cadre observed that, although he had personally preferred the rebel line, he had no choice but to support his factory's loyalist mainstream for fear of jeopardizing his position. 
Before the Cultural Revolution there were hidden problems. When our leadership said something was one, not two, it had to be accepted as one, not two. We could say nothing in response but just had to work more. You could only talk about good things and never about the bad things. During the Cultural Revolution, people talked about anything, without restrictions. People said things they dared not say before. Many things were exposed. If you wanted to say something you said it. Nothing could stop us. It raised people's thinking ... The rebel faction was made up of ordinary small people, people without any power. They felt wronged. You'd been under your supervisor, and there was nowhere to vent your dissatisfaction. It wasn't that I personally felt any anger, but when you joined the rebel faction you felt better. When we talked with each other, we could feel a sense of relief.

In short, such workers appear to have gravitated into the rebel ranks both because of feelings that they and their mates materially had been among the have-nots and also, as this worker observes, because they had felt themselves stifled by a political/administrative hierarchy that had forced them to speak and act against their own interests. Repeatedly, interviewees who had been highschool Rebel Red Guards recalled a similar strong and at times exhilarating sense of release and freedom from the conformist pre-Cultural Revolution tensions they had endured.

Looking back in old age, forty years after the Cultural Revolution upheaval, few of the other interviewees from the distillery share such recollections. Married, with families to look after, they had been simply trying to get through the daily grind of life as best they could, and as they tell it today, the Cultural Revolution turmoil seemed unsettling and at times frightening. In particular, all of the women interviewees look back simply at a time of chaotic violence in the streets, constant worries about their children and personal bafflement. Such feelings are nowhere to be seen in the factional mass-organization newsletters of the Cultural Revolution, nor do they crop up in interviews with former active participants. But these distillery workers' views presumably were shared by many tens of millions of ordinary middle-aged people across China.

Overall, we still know far too little about the circumstances and attitudes of working-class Chinese during the period of the Cultural Revolution. As Elizabeth Perry and Li Xun have noted in their study of Shanghai, "Worker participation was a critical ingredient in the social unrest of the Cultural Revolution decade, but the relative dearth of source materials has made it difficult to address labor's involvement with anything approaching the degree of refinement attained in studies of the student movement". ${ }^{38}$ The published information that I have presented about the groups of workers who participated, and why, was gleaned from the writings of less than a handful of researchers. The extant published information that originates from their interviewees is based on scattered

38 Elizabeth J. Perry and Li Xun, Proletarian Power: Shanghai in the Cultural Revolution, p. 2. Notably, it has become so ingrained in our field to write of the "Cultural Revolution decade” that even Perry and Li inadvertently do so in this quote, even though their book focuses almost exclusively on the Cultural Revolution of 1966-68. 
sources-a single interviewee from one section of one factory, another interviewee from another factory. So far as I know, no one has yet attempted to conduct fieldwork with multiple respondents at a factory site where factional turmoil was rife, to uncover the remembered reasons for participation (or nonparticipation) in one faction or another, and the underlying pre-existing tensions that were exposed in the process.

\section{Government Offices}

I know of only one published discussion of what occurred inside an ordinary government bureaucratic unit. The best Chinese analyst of the Cultural Revolution, Liu Guokai, recounts, in the brief space of about three pages, what happened at his own work unit, the Guangzhou taxation bureau. There, the young bureau chief, who also served as the Party secretary and head of the bureau's political office, was well educated and from a professional family background. An effort to overthrow him was launched by the ambitious head of the bureau's personnel and security section, who was concurrently vice director of the political office. He was from a working-class family, had started as a janitor and had worked his way up as a political activist. He attacked the bureau chief/Party secretary for "having concealed important facts about his family background". But most of the bureau's members turned against the upstart, as they "hated him for his persecution of innocent people ... in his previous work". Liu Guokai himself had been a low-ranking officer in the tax bureau's Communist Youth League branch, and he self-mockingly refers to himself as having been "a bullyboy of the reactionary bourgeois line". He sided with the "conservative" (loyalist) faction and was surprised when several colleagues began to avoid him and set up a Rebel organization:

Being young at the time, I was puzzled at their move. Actually it was simple. These colleagues of mine, though acknowledged activists who had always kept close to the leadership and who contained among them Party members, were none of them political workers but clerical staff members just like myself. But being older and more experienced, they were politically more sensitive and had foreseen that the political and security personnel could not escape being the butt of popular anger. They did not want to accompany them to their funeral. ${ }^{39}$

The most sagacious of all were several clerks in their forties who had worked under the Kuomintang regime, who "surprisingly became conservatives": "They had far more political sensitivity and far-sightedness than my colleagues who had joined the Rebels. Well experienced in life, they were convinced that the Communist Party would not collapse. They took a wait-and-see attitude". ${ }^{40}$

This scenario is quite different from that portrayed in a monograph by Marc Blecher and Gordon White, about what admittedly is not the office of an urban

39 Liu Guokai, “A Brief Analysis”, p. 84.

$40 \quad$ Ibid., pp. 84-85. 
bureau but rather a geological survey unit in the countryside of western China. ${ }^{41}$ Its internal operations, however, were quite similar to those of a government office. Given the technical nature of the work, a majority of the unit's members had senior high school or tertiary educations, and the percentage of middle-class and bad-class personnel among the technicians was relatively high. ${ }^{42}$ Expertise did not equate with political authority, however. Whereas 40 per cent of the unit's members had middling or bad-class backgrounds, not one of the unit's Party members was of bad-class origins and only 7 per cent were of middle-class background. ${ }^{43}$ In the Cultural Revolution, notably, the unit split along class-origin lines in a fashion somewhat similar to China's élite high schools. To quote Blecher and White:

In conclusion, then, class origin seems to have had the greatest independent effect on factional affiliation of all the variables tested. Specifically, people of middling and bad class backgrounds were more likely to join the rebel faction, which expressed their class interests; and people of good class background were more likely to join the conservative faction, whose views on the class issue were consonant with their interests as a class. ${ }^{44}$

The authors add an interesting finding: "that manual workers as an occupational group, regardless of their class backgrounds, were more likely to support the conservative cause than their class backgrounds would predict; i.e., they seem to have acted more in terms of their present class status of worker rather than their class origin or background. As workers, they were more susceptible to appeals by conservative spokesmen and by their own superiors to 'defend the working class' from the attacks of rebels who were more likely to be intellectuals and have 'impure' backgrounds". ${ }^{45}$

It is not too late to enquire about what occurred in other white-collar work units. Potential interviewees are plentiful in urban China today, and some can even be found on university campuses abroad. As a case in point, this morning I conducted an interview with a former employee of China's leading high-tech weaponry design institute. It was an atypical work unit, in that practically everyone who worked there needed to enjoy the very highest level of political trust. Almost all of the employees were Party members. At the beginning of the Cultural Revolution, in what my interviewee calls the "fake Cultural Revolution" (wei wenge) a cadre workteam was dispatched by the national leadership to enter the institute. The workteam leader released the personnel files of two employees who were vulnerable on grounds of political and sexual transgressions, and

\footnotetext{
41 Marc J. Blecher and Gordon White, Micropolitics in Contemporary China: A Technical Unit During and After the Cultural Revolution (White Plains: M. E. Sharpe, 1979). The book's information was based on a single interviewee who had a near-photographic memory.

$42 \quad$ Ibid., pp. 16-17.

$43 \quad$ Ibid., p. 38.

$44 \quad$ Ibid., p. 79.

$45 \quad$ Ibid., p. 81.
} 
sought to channel the institute staff's attacks against the two. But the staff soon broke ranks over solely targeting such tiny fish. The interviewee, who was a young engineer of sterling class background (as were all of the younger staff), recalls that about two-thirds of the institute's employees, including practically all of the engineers and technicians, ultimately joined the rebel faction. They did so not because they held major grievances (all of them, after all, were among China's politically favored, and the material needs of all who worked there were well taken care of). Rather they "rebelled" because of more subtle feelings - in part idealism, in that Chairman Mao had urged rebellion, and in part a desire even among them to be released from the confines of the daily stifling, conformist preCultural Revolution political constraints. As the interviewee notes, the highly educated engineers and technicians were "more independent-minded". (They seem partly akin to the idealistic Qinghua University students described by Xiaowei Zheng in the new book; and partly akin, too, to the worker at the distillery who had chafed at the political constraints of the pre-Cultural Revolution system.) The core of the loyalist faction was composed of political cadres and the institute's blue-collar workers. The interviewee explains that the latter "felt in a privileged position to be at the institute, and so felt loyal" (akin to the blue-collar workers in the geology survey team). There was also a small Middle Faction at the weapons institute largely composed of sons and daughters of well-known national Party leaders, who gradually became bystanders (xiaoyaopai) as the statuses of their own exalted parents became less secure. The interviewee felt that the actual views among the different factions were not far apart, which is not surprising in light of a lack of strong grievances and an absence of political have-nots at the institute. It is also not surprising that no violence and little turmoil occurred here, less so than in any other urban unit that I know about.

Was any aspect of this weaponry design institute's experience of the Cultural Revolution possibly typical? Was the isolated geological survey team's "class"based factional composition more representative of government units? Or was the scenario of the tax office more typical? We have no way of knowing: the available information on what transpired in government units is scanty, to say the least. Interviewing retirees from a number of government bureaus would be necessary to answer such a question.

\section{Villages}

The upheavals in China's vast countryside are considerably better known. The earliest study, by Richard Baum, was published in 1971. Based upon Chinese newspapers and provincial radio broadcasts, Baum was able to discuss the role of Red Guards from county and commune-town high schools, the actions of local officials to ward off, co-opt or repress their activities, the dispatch of army corps into the countryside in 1967 and their subsequent withdrawal, and the final restoration of order in 1968 after directives from Beijing to enforce the 
establishment of so-called "revolutionary committees" in each locale. ${ }^{46}$ In the three and a half decades since Baum's essay, more than a dozen village studies have been published that chronicle the recent histories of farming communities; ${ }^{47}$ and scattered new documentation from China has also become available. In addition, over the decades I have been able to carry out interviews with people from 31 villages. ${ }^{48}$ Based on these sources, it becomes possible to delineate some of the elements of the Cultural Revolution turmoil in China's villages.

First, it becomes clear that upheavals were much more common than could be discerned from the newspapers and broadcasts to which Baum had access. Only slightly more than a third of the villages of my interviewees-eleven, to be exact-rode out the Cultural Revolution without any armed struggles between

46 Richard Baum, “The Cultural Revolution in the Countryside: Anatomy of a Limited Rebellion”, in Thomas W. Robinson (ed.), The Cultural Revolution in China (Berkeley: University of California Press, 1971), pp. 367-476. By carefully piecing together where and when various types of incidents were reported to have occurred in the countryside, Baum was able to draw up an interesting chronological account of how the Cultural Revolution developed in the countryside, an account that examined the movement's ultimate spatial distribution. His documentary evidence suggested that the bulk of the commune towns and rural villages which experienced upheavals lay relatively close to cities, railway lines, major roads or ports and that, generally, the closer they were, the earlier they experienced Cultural Revolution turmoil.

47 Zhang Letian, Gaobie lixiang: Renmin gongshe zhidu yanjiu (Departing from Ideals: Research into the System of the People's Commune) (Shanghai: Dongfang Chubanshe, 1998), pp. 205-14; Zhu Xiaoyang, Zuiguo yu chengfa: Xiaocun gushi 1931-1997 (Crime and Punishment: The Tale of a Small Village 1931-1997) (Tianjin Guji Chubanshe, 2003), pp. 127-32; Edward Friedman, Paul G. Pickowicz and Mark Selden, Chinese Village, Socialist State (New Haven: Yale University Press, 1991), pp. 87-116; William Hinton, Shenfan: The Continuing Revolution in a Chinese Village (New York: Random House, 1983), pp. 509664; Mobo Gao, Gao Village: Rural Life in China Since the Revolution (London; Honolulu: Hurst \& Co.; University of Hawaii Press, 1999), pp. 144-54; Philip Huang, "Rural Class Struggle in the Chinese Revolution: Representational and Objective Realities from the Land Reform to the Cultural Revolution”, Modern China, Vol. 21, No. 1 (January 1995), pp. 105-43; Huang Shu-min, The Spiral Road: Change in a Chinese Village Through the Eyes of a Communist Party Leader (Boulder: Westview Press, 1989), pp. 89-98; Peter Seybolt, Throwing the Emperor from his Horse: Portrait of a Village Leader in China (Boulder: Westview Press, 1996), pp. 65-72; Sulamith Heins Potter and Jack M. Potter, China's Peasants: The Anthropology of a Revolution (Cambridge: Cambridge University Press, 1990), pp. 83-90; Gregory A. Ruf, Cadres and Kin: Power, Authority, and Corporatism in a West China Village, 1937-1991 (Stanford: Stanford University Press, 1998), Ch. 7; Helen F. Siu, Agents and Victims in South China (New Haven: Yale University Press, 1989), pp. 2048; Anita Chan, Richard Madsen and Jonathan Unger, Chen Village Under Mao and Deng (Berkeley: University of California Press, 1992), Ch. 4; and Richard Madsen, Morality and Power in a Chinese Village (Berkeley: University of California Press, 1984), Ch. 6.

48 I have drawn upon those materials in Jonathan Unger, "Cultural Revolution Conflict in the Villages”, The China Quarterly, No. 153 (March 1998), pp. 82-106, and also Jonathan Unger, The Transformation of Rural China (Armonk: M. E. Sharpe, 2002), Ch. 3. The following paragraphs about China's villages rely upon these previous writings. 
hamlets or villages or serious eruptions from below. ${ }^{49}$ Among the villages that did experience conflicts, a considerable portion were of a traditional nature. For instance, disputes between villages over land and over access to water revived in 1967-68 when the local Party hierarchies and local governments collapsed. In ten of the villages of interviewees and in several of the published village studies, historically rooted conflicts between a village's different lineage groups also erupted, many of which involved struggles between lineages to capture a village's leadership posts. In a number of villages, though, the conflicts were quite non-traditional, generated by tensions between a village's overbearing Party cadres and disgruntled farmers or by hostility between cadres stirred up by the Party's recent Four Cleanups Campaign..$^{50}$ Complicating events, a large number of the villages that witnessed conflicts of a traditional nature also witnessed upheavals that were directly related to the nature of Party rule.

Given a need to justify attacks and counter-attacks during the Cultural Revolution by way of "ideology", both the traditionally-based rivalries and the non-traditional antagonisms often were clothed in socialist rhetoric and got acted out in a new "revolutionary" mode of stylized conflict. The Mao quotations that got brandished encouraged an exaggerated, uncompromising righteousness and intolerance and a recourse to violence to destroy resistance. This extreme politics of the Cultural Revolution period meant, quite realistically, that losing out in a struggle was likely to entail severe persecution. Such fears fueled mounting cycles of violence and counter-violence, in cities as well as in the countryside, among worker and student groups as well as among farmers and the selfinterested contenders for rural political power. Regarding the Cultural Revolution in her own village, one interviewee observed that "seeking revenge afterwards is very common in China, and that's why people beat their victims down so hard: because they're afraid that if they can rise again they might take revenge. So you feel you need to totally demolish them".

A second form of rural violence was also common. As the Cultural Revolution began to seep outwards from the cities, many commune and village officials began to organize farmers to mete out severe persecution against the bad-class households. The local leaders obviously saw it as a means of selfprotection to preside over such persecutions. They could see that one of the charges being leveled against urban Party leaders during the Cultural Revolution was that they had been insufficiently militant on behalf of Chairman Mao's class line, and so rural Party officials became especially anxious to demonstrate their

49 When I write that a third of the villages did not experience Cultural Revolution turmoil from below, I am not including persecutions mounted from above by officials, nor orchestrated movements to struggle against and physically abuse bad-class people. The latter occurred almost everywhere, and was not confined to the Cultural Revolution of 1966-68: such persecutions were commonplace throughout most of the period of Mao's rule.

50 An example of the latter is described, for example, in Anita Chan, Richard Madsen and Jonathan Unger, Chen Village, Chs. 2-4. 
militancy in pursuit of bad-class enemies. They convened public meetings at which bad-class people were "struggled against" and in some cases killed. ${ }^{51}$

How the Cultural Revolution turmoil differed in different types of rural districts, and why, remains unclear. A far wider range of local accounts needs to be gathered and analyzed.

\section{County towns}

The residents of the county capitals and commune market towns had a different type of residence permit (hukou) than the farmers, and this provided them with a distinctly different set of circumstances in life. Most of them worked in urbanlike work units that paid regular salaries. Economically, socially and politically, their lives more closely resembled that of urban residents rather than villagers. It is not altogether surprising that the conflicts that embroiled many of the county capitals and commune towns during the Cultural Revolution closely followed the same chronology of events as the cities, or that the same type of factionalism arose there. ${ }^{52}$ This is clear from the descriptions in county gazetteers and also from interviews that I conducted with several former residents of towns. An interviewee relates that in his own town, which was a commune headquarters/market center, the commune clerks organized their own Rebel group.

At about the same time that upheavals and factionalism began to emerge in the towns, in a large number of counties the county and commune militia commanders became far more visible. As provincial Party organs collapsed in early 1967, Party leaders at the county level sometimes strategically withdrew from their posts and let the militia commanders, who were protected by their military connections to the regional army command, pretend to assume authority, while the county and commune Party leaders continued to control events from behind the scenes. In other cases, where the militia commanders were politically

51 Notably, during the Cultural Revolution nothing was more dangerous to a non-bad-class person than to be depicted and denounced in bad-class terms. In the horrific accounts of the Chinese author Zheng Yi about the murders of overthrown local officials and factional enemies in rural Guangxi, again and again such victims were beaten and slaughtered alongside bad-class people in a single orgy of killing, treating them as one and the same, as if to cement this linkage in the minds of both onlookers and perpetrators. A substantial number of such incidents are described in Section One (pp. 2-116) of Zheng Yi's book Hongse jinian bei (The Red Memorial Plinth) (Taipei: Huashi Wenhua Gongsi, 1993). One particularly chilling example is on p. 25.

52 There has been some confusion over this important distinction between the urban-like towns and the rural villages. This is exemplified by an article in The China Quarterly (March 2003) by Andrew Walder and Yang Su titled "The Cultural Revolution in the Countryside", which largely focuses not on the countryside but rather on what occurred in the county towns, on the factional fighting that originated there, and the mass killings that were directed from there. The major events within each county that it examines are "an attempted power seizure by a mass organization; an armed battle between two factions; and the establishment of a [county-level] revolutionary committee” (p. 83). Cultural Revolution mass organizations and factional fighting were both urban and county-town-centered phenomena. 
ambitious, they used the opportunity to make a play for real power at the county capital or commune. ${ }^{53}$

Both in rural communes where the status quo had won out against local opposition and in those where it had never been challenged, the commune authorities were apt to support the so-called loyalist-faction mass organizations of the county and prefectural capitals. The loyalist faction's membership tended to derive from among those people in the county towns who had been politically favored prior to the Cultural Revolution. The faction therefore tended to uphold the pre-Cultural Revolution county and prefectural leaders. This appealed to commune and village Party leaders. Their loyalty to their pre-Cultural Revolution superiors often appears to have remained informally intact. In many cases, such feelings of loyalty especially linked the communes' militia commanders to the county militia headquarters, and in turn to the county's Party and government leadership. The plight of the county-town authorities, under threat from countytown Rebel mass factions, might not, in itself, have prompted the rural leaders and commune militia commanders to become militarily involved. But in addition to their sympathy, they appear to have been fearful that a victory by the countyseat or urban-based rebel factional alliance would jeopardize their own continued hold on power in the countryside. When the rural authorities received urgent calls to come to the aid of embattled county and prefectural leaders or to the rescue of flagging county-town or prefectural-city Loyalist factions, the militia corps of farmers were ordered out of the villages and dispatched to do their duty. ${ }^{54}$ Armed attacks by county and commune militias against Rebel organizations were often launched at the county capital and then, when the rebellious forces there were crushed, progressively proceeded outward and upward toward the provincial capital, entering some of the cities to crush urban Rebel organizations bloodily. ${ }^{55}$

53 This information derives from several interviewees. The assumption of authority by the militia heads can also be observed in the county gazetteers and Zheng Yi's volume: again and again in these published sources, the leaders in the county Revolutionary Committees and at commune level who ordered massacres in 1968, or instructed villages to do so, are identified as militia commanders.

54 The militiamen often received remuneration for doing so. As a Jiangsu provincial radio broadcast of August 1967 complained, "In some regions they practice counter-revolutionary economism and give supplementary workpoints, money and grain to commune members to take part in fighting ... all to incite the peasants to enter the cities to fight the revolutionary mass organizations in factories, mines, administrative bureaux, and schools". (Quoted in China News Analysis, No. 679 [29 September 1967], p. 2). In two of the villages in my interview sample, ordinary villagers were paid in workpoints for attending, in massed groups, vast struggle meetings that the commune authorities organized at the commune market town.

55 In Guangxi Province, in Guilin, the provincial capital of Nanning, and other cities, county militias aligned to the Loyalist camp ultimately surrounded the cities and perpetrated massacres. On this, see Hua Linshan, Les Années Rouges. Liu Guokai lists six other provinces where such assaults on cities were also widespread, and he writes, "Whereas urban residents, workers, students, and other members of the 'conservative' [loyalist] faction still held back a little in fighting the rebels for fear of accidentally hitting good people, outof-town peasants had no such inhibitions; they went all the way, killing, burning, looting. 
The county-led militias were also deployed downward in the initial part of the Cleansing of Class Ranks campaign in 1968. Their commanders and the commune-town militia commanders under them orchestrated many of the local mass killings, as is clear from the available documentation and interview accounts. Much of the statistics on mass killings that Yang Su gathered for his chapter appear to derive from these massacres.

One puzzle is why the brutality perpetrated under the direction of leaders based in towns became, on the whole, greater than what city residents engaged in. Certainly, the cities experienced murderous brutality, as in the secondary schools of Beijing in the early period of the Cultural Revolution..$^{56}$ But the cities did not witness the surge of mass slayings of bad-class people as occurred in some counties and villages. Nor, unlike many counties, were there widespread massacres in the cities of members of the losing faction in the initial phases of the Cleansing of Class Ranks campaign, with the exception of cities stormed by county militia. ${ }^{57}$ What was the psychology that rendered the county towns and rural militias more brutal in their treatment of prisoners? Might one reason be that the factional fighting in the towns had been more murderous than in the cities? If so, had pre-Cultural Revolution grievances, animosities and tensions been greater in towns than in cities? We have no answers, because we do not have sufficiently detailed knowledge about what occurred in even a single county or commune town during the Cultural Revolution. ${ }^{58}$ Such research is needed.

\section{Ethnic minorities}

The available evidence from areas inhabited by non-Han peoples strongly suggests that, during the Cultural Revolution, Han officials interpreted such people's nonconformity to the majority Han way of life as deviations from Chairman Mao's teachings. Efforts were often made by officials and mobs alike to impose Han mores by destroying the ethnic-minority people's religious sites and enforcing Han social practices. But we know all too little about what occurred, or the degree to which ethnic-minority youths themselves participated in the onslaughts, or whether

Many cities were under siege, forcing non-partisan city-dwellers to guard the cities together with the rebels to prevent their fall into the hands of the peasants, whose barbarity made no distinction between rebels and ordinary citizens”. Liu Guokai, “A Brief Analysis”, pp. 9798.

56 A large number of shocking cases are described in Wang Youqin, Wenge shounanzhe (Victims of the Cultural Revolution) (Hong Kong: Kaifang Zazhi Chubanshe, 2004).

57 In the city of Guangzhou, which was never invaded but where the Rebel faction was suppressed by the city's army command in August 1968, the top several leaders of the citywide high-school Rebel Red Guard alliance were neither killed nor beaten by the victors. While the top commander of the Rebel Red Guards was imprisoned for two years, almost all of the other high-school Rebel leaders, including the deputy commander, were simply assigned in 1968 to work in villages alongside most of their schoolmates of both factions. On this, see Anita Chan, Children of Mao, pp. 157, 163, 191, 194.

58 The events in a county town are described in Gao Yuan's interesting memoir, Born Red (Stanford: Stanford University Press, 1987), but Gao Yuan was a boy at the time and the events are portrayed from that perspective. 
many ethnic communities split into factions caused by internal tensions, as occurred elsewhere in China. ${ }^{59}$

We do know that during the Cultural Revolution brutal persecutions were carried out against several ethnic groups whose loyalty to China was considered suspect. The worst reported persecutions occurred in Inner Mongolia, where Mongols were accused of conspiring to betray China. Hundreds of thousands of Mongols, many of them from the countryside, were arrested in a witch hunt, and tens of thousands were killed while in detention. ${ }^{60}$ There is less information about the persecution of other ethnic peoples, or about the underlying animosities that sparked persecutions.

\section{A Needed Agenda}

In short, a great deal about the Cultural Revolution at the grass roots remains relatively unknown to us. We have only a scant idea, for instance, about what occurred at China's state farms. We know very little about what occurred in China's service sectors or hospitals or, say, among sailors on Chinese ships. It is possible to compile a lengthy list of the sectors of China's populace about which we know very little-how they experienced the Cultural Revolution, how and why they split into contending factions, or what underlying grievances and animosities motivated the violent divisions. As seen in the preceding pages, renewed research is also needed about those sectors on which some research has been conducted but about which our knowledge is still too fragmentary-be it the universities outside Beijing, factories, government offices, rural China, county towns or China's ethnic peoples.

59 The anthropologist Erik Mueggler provides evidence from one village, an Yi community in Yunnan province, showing that such a split did occur there. During both the preceding Socialist Education (Four Cleanups) campaign and the early Destroy Four Olds period of the Cultural Revolution, local officials and political activists who were themselves Yi ridiculed and violated some local religious practices as “superstition”. But by early 1967, the village government was overthrown, and two rival Red Guard groups emerged, which battled each other. The village's political establishment lost out, and vengeance was exacted against all those who had been in charge of the village during the hated Great Leap Forward. They were beaten mercilessly during nightly "struggle sessions" attended by most villagers. The village's Party secretary committed suicide, and his wife, who had been among those responsible for violating a sacred reliquary box, soon also died. By late 1969, the period of the Cleansing of Class Ranks campaign, the tables were turned, and upstart Red Guards and village shamans and diviners were in turn beaten in struggle sessions. Erik Mueggler, The Age of Wild Ghosts: Memory, Violence, and Place in Southwest China (Berkeley: University of California Press, 2001), pp. 258-63.

60 On this, see William R. Jankowiak, “The Last Hurrah? Political Protest in Inner Mongolia”, The Australian Journal of Chinese Affairs, No. 19-20 (January-July 1988), pp. 273-88; also W. Woody [pseudonym for a Chinese author], The Cultural Revolution in Inner Mongolia (Stockholm: Center for Pacific Asia Studies at Stockholm University, Occasional Paper 20, 1993), 41 pp.; also, with terrifying details, Zheng Yi, Hongse jinian bei, pp. 285-92, and Wu Di, "Neirendang da xue'an shimo" (The Major Cases of Murder vis-à-vis the 'Inner Mongolian Revolutionary Party', from Beginning to End), in Song Yongyi (ed.), Wenge da tusha (Major Massacres of the Cultural Revolution) (Hong Kong: Kaifang Zazhi She, 2002), pp. 59-110. 
The principal message of this essay is that, to comprehend Chinese society and its discontents during the period of Mao's rule, such research should again become part of our field's agenda, soon, before time runs out.

What is evident from the research already conducted is that a complicated mix of pre-existing grievances and animosities got played out and amplified in the strife of the Cultural Revolution. Across a number of sectors of society, as has been observed, splits arose between those who had been successful political activists and had gained the trust of superiors as against those who had not been inclined to be politically activist and felt badgered and restrained by the politically favored. We have observed this scenario, for instance, in the high schools of working-class students, in government offices and in factories. Separately, we have observed tensions arising from the uneven treatment faced by people who bore good-class and middle-class family-origin labels. We have seen how this influenced divisions into opposing factions in high schools and in cases arising in a government office (a geological survey team) and a university. We have also observed a separate cause of hostility and factional alignment arising from relative material deprivation-as seen among the temporary and contract workers, apprentices, and the workforces of small peripheral factories and disfavored occupations. We have also witnessed how groups took advantage of the political instability to launch efforts to improve their positions politically, one example being the effort by disgruntled lineages to oust village leaders who belonged to, and favored, other village lineages. Finally, we have observed how the Party's teachings gave rise in the heat of the Cultural Revolution to repression of non-Han practices and how the political teachings on "class struggle" and hidden enemies prompted politically insecure officials to mount extraordinary displays of murderous violence against people of bad-class origins and against groups such as China's Mongols.

In different types of work units and communities across China, one or the other of the above forms of antagonisms took precedence, as has been seen. Even so, several of these causes of tension were usually operating at one and the same time, lending added complexity to the splits into opposing factions and contributing to a dangerous brew of escalating violence. But we are not well enough informed about what elements were most significant, with what impact, in the various sectors of society. Nor do we have a grasp of whether there were regional differences, and if so, why. Nor do we have a good enough grasp of the social psychology of the period. Simply to reveal grievances does not explain the passion with which so many people responded, nor their beliefs at the time that they were acting righteously.

But above all, it is important to first gain a better handle on the divisions in each sector of society that drove people into contending factions. As noted, these schisms revealed the tensions at the grassroots not only for this extraordinary period but also for the years preceding the Cultural Revolution. More than that, many of the same tensions persisted throughout the 1970s, once again largely concealed from view, after the mass upheavals were suppressed in 1968 and the system of political hierarchy and social repression was reimposed. In short, studying the Cultural Revolution upheavals of the late Sixties provides us with a window into understanding more about almost the whole sweep of the Maoist period. The years 1966-68, and the Pandora's box that opened up then, are truly crucial to study. 